\title{
Hvorfor ortogeriatri?
}

\author{
Om lag 9000 personer i Norge får et brudd i øvre femurende hvert år. Denne pasientgruppen er sårbar - \\ med mange komorbide tilstander, høyt legemiddelforbruk og høy prevalens av demens. Prognosen er \\ alvorlig. Et strukturert samarbeid mellom spesialister i ortopedi og geriatri gir bedre behandlingsresultat \\ for pasientene og nye vitenskapelige innfallsvinkler.
}

Norge er på verdenstoppen i antall hoftebrudd (lårhalsbrudd, pertrokantære eller subtrokantære brudd). For personer over 50 år her i landet er den aldersjusterte insidensen av hoftebrudd estimert til 82 per 10000 kvinner og 39 per 10000 menn, høyere enn i noe annet europeisk land (1). For 364 pasienter med hoftebrudd i Oslo i 2005-06 var medianalderen 84 år, $43 \%$ hadde sannsynlig demens på bruddtidspunktet, de brukte i gjennomsnitt fire legemidler daglig, og $46 \%$ hadde delirium i den perioperative fasen (2).

Prognosen er alvorlig, både hva angår motorikk, selvhjulpenhet og kognisjon: $42 \%$ av pasientene oppnår aldri samme gangfunksjon som for bruddet (3), $58 \%$ skrives ut til sykehjem (4), og insidensen av nyoppstått demens er høy de første månedene etter bruddet (5).

Et hoftebrudd er derfor vanligvis en ortopedisk skade $i$ et individ preget av generell sårbarhet. Rask, skånsom og god kirurgisk reparasjon av skaden har førsteprioritet, er livreddende og forebygger komplikasjoner. Primær innsetting av protese regnes i dag som foretrukket behandling ved de aller fleste tilfeller av lårhalsbrudd (6), mens perog subtrokantære brudd behandles med osteosyntese; glideskrue med plate eller margnagle. For de fleste hoftebruddspasienter er ikke dette nok. Håndtering av deres komplekse helseproblemer krever en multimodal tilnærming for at resultatet skal bli optimalt.

\section{Ortogeriatri virker}

I lang tid har det vært argumentert for at strukturert ortopedisk-geriatrisk samarbeid måtte være gunstig når det gjelder denne pasientgruppen, og etter hvert har begrepet «ortogeriatri» vokst frem. I en fersk systematisk oversikt var det vanskelig å gjennomføre noen formell metaanalyse, fordi studiene hadde ulike effektmål og ulike modeller ble testet. Man fant likevel en tendens i retning av at samarbeidsmodeller med tett integrasjon av den ortopediske og den geriatriske spisskompetansen rundt øremerkede senger var mest lovende, mens det var vanskelig å finne positiv effekt av modeller der for eksempel et ambulant geriatrisk team ga råd om pasienter som var innlagt $i$ en rent ortopedisk sengepost (7).

Nylig er to randomiserte, kontrollerte studier av ortogeriatriske modeller i Norge publisert $(8,9)$. I begge studiene testet man modeller der intervensjonspasientene pri- mært var innlagt i geriatriske sengeposter og fikk ortopedisk tilsyn ved behov. Kontrollpasientene lå i konvensjonelle ortopediske sengeposter og hadde geriatrisk eller annet indremedisinsk tilsyn ved behov. Hovedelementer i intervensjonen i begge studiene var en bred klinisk vurdering av relevante helseforhold, koordinert tverrfaglig samarbeid, strukturering av arbeidet med sjekklister og protokoller, tidlig mobilisering og tidlig utskrivningsplanlegging.

Den ene studien ble gjennomført i Trondheim og inkluderte bare pasienter som var hjemmeboende da bruddet inntraff (8). Hovedendepunktet var mobilitet målt med instrumentet Short Physical Performance Battery (SPPB). Ortogeriatrigruppen

\section{«Et hoftebrudd er en ortopedisk skade i et individ preget av generell sårbarhet»}

hadde en høyere SPPB-skår etter fire og 12 måneder enn gruppen som fikk standard ortopedisk behandling, og forskjellen var statistisk signifikant. Ortogeriatrigruppen hadde også bedre resultater med hensyn til funksjon og livskvalitet, og de var mindre redde for å falle. Liggetiden var gjennomsnittlig 1,7 døgn lengre i ortogeriatrigruppen, men mer enn dobbelt så mange ble utskrevet direkte fra sykehus til hjemmet, og det første året etter bruddet hadde gjennomsnittspasienten 2,7 færre liggedøgn i sykehus, fire færre døgn i rehabiliteringsinstitusjon og 13 færre døgn i sykehjem enn ortopedigruppen. Gjennomsnittlig kostnadsreduksjon var vel 40000 kroner per pasient det første året.

Den andre studien ble gjennomført i Oslo, og omfattet både hjemmeboende hoftebruddspasienter og pasienter som kom fra sykehjem (9). Hovedmålsettingen med denne studien var å undersøke om en ortogeriatrisk modell kunne forebygge delirium og akselerert kognitiv svikt. Vi fant ingen effekt av ortogeriatrisk behandling på kognitiv svikt og delirium, derimot ble det påvist samme forskjell i SPPB-skår hos hjemmeboende pasienter som Trondheimsstudien. Samlet gir disse to studiene derfor vesentlig styrket indikasjon på at et orto- geriatrisk tilbud til hjemmeboende pasienter med hoftebrudd har en klinisk betydningsfull positiv effekt på mobilitet og gangfunksjon minst ett år etter bruddet.

\section{Forebygging av nye brudd}

Forebygging av nye brudd har to komponenter: Bremse osteoporoseutviklingen og forebygge fall. Det første er enklest, men selv med dagens gode kunnskap om nytten av behandling med beinresorpsjonshemmere er det etter vår erfaring få hoftebruddspasienter som får slike legemidler.

Nye fall etter et hoftebrudd er vanlig. I en studie fant man at $56 \%$ av pasientene med hoftebrudd opplevde et nytt fall i løpet av det første året. $12 \%$ av disse fallene resulterte $\mathrm{i}$ et brudd og $5 \%$ i et nytt hoftebrudd (10). Årsakene til fall er mange og sammensatte, og utreding av falltendens hos pasienter med mange kroniske sykdommer og uklar fallårsak er en typisk geriatrisk oppgave (11). Muligens vil optimalisert rehabilitering etter utskrivning fra sykehus bedre effekten av et ortogeriatrisk tilbud ytterligere. I Trondheim er datainnsamlingen i en randomisert studie av intensiv hjemmebasert fysioterapi 4-6 måneder etter hoftebrudd nylig avsluttet. Endepunktene er gangfunksjon og fysisk aktivitet i dagliglivet (12).

Hvorfor prioriteres ikke ortogeriatri? Til tross for god kunnskap og klinisk betydningsfulle resultater for en pasientgruppe med alvorlig prognose har det vist seg vanskelig å få sykehusene til å prioritere opprettelsen av ortogeriatriske enheter. Vi tror dette skyldes at det kreves satsing på tvers av tradisjonelle skillelinjer mellom fag og avdelinger, at det kreves friske økonomiske midler fordi ortogeriatri innebærer å investere mer klinisk innsats i en forsømt pasientgruppe, og at hoftebruddspasientene er en svak gruppe med små muligheter til å tale egne interesser.

Flere ortopediske avdelinger har omorganisert behandlingsopplegget for pasienter med hoftebrudd med tanke på rask operasjon og et akselerert forløp videre (fast track). Et slikt opplegg har mange gode elementer, som redusert preoperativ ventetid, bedre analgesi og raskere mobilisering, men disse modellene mangler et system for ivaretakelse av hoftebruddpasientenes uttalte komorbiditet, polyfarmasi og geriatriske komplikasjoner. De har ikke gitt effekt i randomiserte studier når det gjelder kliniske endepunkter. Vi tror det mest realistiske nå er at ortopeder og geriatere gjør fel- 
les sak, starter et samarbeid og krever forbedring i tilbudet til denne svake gruppen.

Det er fortsatt et stort behov for forskning, særlig gjelder det å finne optimale tjenestemodeller for akuttbehandling (inkludert forebygging og behandling av delirium), rehabilitering og multimodal forebygging av nye brudd. Også her tror vi et nært ortopediskgeriatrisk samarbeid kan være fruktbart og bidra til å få frem gode løsninger.

Vi planlegger derfor et forskningssamarbeid som omfatter ortopediske og geriatriske miljøer i Trondheim og Oslo og håper det vil kunne bidra til å gi et nasjonalt løft for behandlingen av hoftebruddspasienter. Man bør på sikt utarbeide nasjonale retningslinjer for håndtering av skrøpelige eldre med brudd, slik man har gjort i England. Der har et grundig arbeid drevet frem i fellesskap av British Orthopaedic Association og British Geriatrics Society ført til detaljerte og gode retningslinjer for alle aspekter ved dette (13). I disse retningslinjene er betydningen av ortogeriatrisk samarbeid sterkt vektlagt.

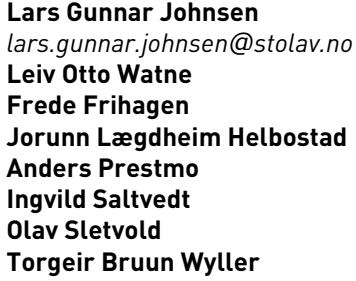

Lars Gunnar Johnsen (f. 1964) er spesialist i generell kirurgi og i ortopedisk kirurgi, med spesialfelt ortopedisk traumatologi. Han er overlege ved Ortopedisk traumeseksjon, St. Olavs hospital, og førsteamanuensis ved Institutt for nevromedisin, Norges teknisknaturvitenskapelige universitet.

Forfatter har fylt ut ICMJE-skjemaet og oppgir ingen interessekonflikter.

Leiv Otto Watne (f. 1977) er lege i spesialisering $\mathrm{i}$ indremedisin og i geriatri og postdoktor ved Institutt for klinisk medisin, Universitetet i Oslo. Forfatter har fylt ut ICMJE-skjemaet og oppgir ingen interessekonflikter.
Frede Frihagen (f. 1967) er spesialist i ortopedisk kirurgi, med spesialfelt ortopedisk traumatologi, overlege ved Ortopedisk avdeling. Oslo universitetssykehus, og forsker.

Forfatter har fylt ut ICMJE-skjemaet og oppgir følgende interessekonflikter: Han har mottatt forskningsbidrag/honorar fra Eli Lilly Norge, Amgen og Takeda Nycomed.

Jorunn Lægdheim Helbostad (f. 1961) er fysioterapeut og professor i bevegelsesvitenskap ved Institutt for nevromedisin, Norges teknisknaturvitenskapelige universitet. Hun har også en stilling ved Klinikk for kliniske servicefunksjoner, St. Olavs hospital.

Forfatter har fylt ut ICMJE-skjemaet og oppgir ingen interessekonflikter.

Anders Prestmo (f. 1969) er spesialist i indremedisin, i endokrinologi og i nyresykdommer. Han er overlege ved Avdeling for geriatri, St. Olavs hospital, og stipendiat ved Institutt for nevromedisin, Norges teknisk-naturvitenskapelige universitet.

Forfatter har fylt ut ICMJE-skjemaet og oppgir ingen interessekonflikter.

Ingvild Saltvedt (f. 1960) er spesialist i indremedisin og i geriatri, overlege ved Avdeling for geriatri, St. Olavs hospital, og forsker og førsteamanuensis ved Institutt for nevromedisin, Norges teknisk-naturvitenskapelige universitet. Forfatter har fylt ut ICMJE-skjemaet og oppgir ingen interessekonflikter.

Olav Sletvold (f. 1949) er spesialist i indremedisin og i geriatri, avdelingssjef ved Avdeling for geriatri, St. Olavs Hospital, og professor ved Institutt for nevromedisin, Norges teknisknaturvitenskapelige universitet.

Forfatter har fylt ut ICMJE-skjemaet og oppgir ingen interessekonflikter.

Torgeir Bruun Wyller (f. 1960) er spesialist i indremedisin og i geriatri, professor i geriatri ved Universitetet i Oslo og overlege ved Geriatrisk avdeling, Oslo universitetssykehus.

Forfatter har fylt ut ICMJE-skjemaet og oppgir ingen interessekonflikter.

\section{Litteratur}

1. Støen RO, Nordsletten L, Meyer HE et al. Hip frac ture incidence is decreasing in the high incidence area of Oslo, Norway. Osteoporos Int 2012; 23: 2527-34.

2. Juliebø V, Bjøro K, Krogseth M et al. Risk factors for preoperative and postoperative delirium in elderly patients with hip fracture. J Am Geriatr Soc 2009: 57: 1354-61.

3. Bertram M, Norman R, Kemp L et al. Review of the long-term disability associated with hip fractures. Inj Prev 2011; 17: 365-70

4. Bentler SE, Liu L, Obrizan M et al. The aftermath of hip fracture: discharge placement, functional status change, and mortality. Am J Epidemiol 2009; 170: 1290-9.

5. Krogseth M, Wyller TB, Engedal K et al. Delirium is an important predictor of incident dementia among elderly hip fracture patients. Dement Geriatr Cogn Disord 2011; 31: 63-70.

6. Frihagen F, Nordsletten L, Madsen JE. Hemiar throplasty or internal fixation for intracapsular displaced femoral neck fractures: randomised controlled trial. BMJ 2007; 335: 1251-4.

7. Grigoryan KV, Javedan H, Rudolph JL. Orthogeriatric care models and outcomes in hip fracture patients: a systematic review and meta-analysis. J Orthop Trauma 2014: 28: e49-55.

8. Prestmo A, Hagen G, Sletvold 0 et al. Comprehensive geriatric care for patients with hip fractures: a prospective, randomised, controlled trial. Lancet 2015. E-publisert 4.2

9. Watne LO, Torbergsen AC, Conroy S et al. The effect of a pre- and postoperative orthogeriatric service on cognitive function in patients with hip fracture: randomized controlled trial (Oslo Orthogeriatric Triall. BMC Med 2014: 12: 63

10. Lloyd BD, Williamson DA, Singh NA et al. Recurrent and injurious falls in the year following hip fracture: a prospective study of incidence and risk factors from the Sarcopenia and Hip Fracture study. J Gerontol A Biol Sci Med Sci 2009. 64 : $599-609$

11. Smebye KL, Granum S, Wyller TB et al. Medisinske funn i en tverrfaglig geriatrisk fallpoliklinikk. Tidsskr Nor Legeforen 2014: 134: 705-9.

12. Thingstad $P$, Taraldsen $K$, Hagen $G$ et al. Effectiveness of task specific gait and balance exercise 4 months after hip fracture: protocol of a randomized controlled trial - the Eva-Hip Study. Physiother Res Int 2014. E-publisert 3.7.

13. The care of patients with fragility fracture. London: British Orthopaedic Association, 2007. www.nhfd.co.uk/20/hipfractureR.nsf/ welcome?readform (1.9.2014)

Mottatt 11.2. 2015, første revisjon innsendt 18.2. 2015, godkjent 2.3. 2015. Redaktør: Lise Mørkved Helsingen.

Publisert først på nett. 